\title{
Edyta Paczka
}

ORCID: 0000-0003-4811-8414

Uniwersytet Wrocławski

edyta.paczka@uwr.edu.pl

\section{Zmiana zachowań rynkowych pokolenia Z}

Artykuł nadesłany: 7.01.2020; artykuł zaakceptowany: 25.05.2020

Kody klasyfikacji JEL: D16, D90, Q01, Q56

Keywords: generation Z, changes in consumer behaviour, innovations in consumption, collaborative consumption, prosumption

\section{Abstract \\ Generation Z change in market behaviour}

This article presents considerations on the changes of the consumer behaviour of generation $\mathrm{Z}$, manifested in the way purchasing decisions are made and needs are met. The purpose of this article is to analyse the conditions for the development of new forms of purchasing processes and alternative consumption patterns. The author pointed out factors causing young purchasers' increased interest in innovative solutions in the sphere of consumption, and, in particular, the expanding scope of internet communication and the scale of use of mobile devices. It has been proved that the generation $\mathrm{Z}$ consumption model is strongly embedded in virtual reality and includes an alternative approach to satisfying needs.

An attempt was made to answer the question regarding the reason for a change in approach of the youngest generation to consumption and the development of new trends, and in particular of the resignation from purchasing goods in favour of gaining access to them. The author indicated certain premises increasing generation Z's inclination to use some goods or services only when required, and not acquiring them for personal possession, including, in particular, growing awareness of the negative social and environmental consequences of excessive consumption. Benefits of adapting the collaborative consumption model in the form of prosumer activities were highlighted. The presented topic allowed to show the changing approach to consumption as a challenge for enterprises facing the need to react both to the changing mobile technological environment and to the new, emerging generation of consumers. So far, this problem has not been studied in detail, therefore the conclusions of the article on changing consumer attitudes of generation $\mathrm{Z}$ may be used by manufacturers to take actions consistent with the expectations of this significant group of young, mobile buyers. 


\section{Wstęp}

Rozwój technologiczny wpływa na zachowania współczesnych konsumentów, którzy znaczną część swojej aktywności realizują w przestrzeni wirtualnej, gdzie nawiązują kontakty, wymieniają się informacjami i dokonują zakupów. B. Mróz jest zdania (2013, 139-140), że konsumenci XXI wieku przekształcili się w trysumerów (trying consumer — konsument próbujący, poszukujący), którzy osobiście weryfikują ofertę rynkową, poszukują nowych wariantów zaspokajania potrzeb, a przy podejmowaniu decyzji opierają się na doświadczeniach własnych lub innych użytkowników. Z kolei A. Krzepicka $(2016,212)$ określa współczesnych konsumentów mianem konsumentów nowej ery lub konsumentów digitalnych, którzy regularnie robią zakupy w e-sklepach oraz są otwarci na rozwiązania mobilne. Odznaczają się niezależnością, podkreślają swoją indywidualność, a zarazem autentyczność, angażują się w procesy rynkowe oraz zbierają, analizują i selekcjonują informacje. Jak dowodzi K. Włodarczyk-Śpiewak (2011, 145), nowoczesny konsument w swoim postępowaniu uwzględnia przesłanki etyczne. Dostrzega negatywne konsekwencje swoich zachowań i stara się im zapobiegać. Z konsumenta reprezentującego postawę hedonistyczną i egoistyczną przekształca się w konsumenta moralnie odpowiedzialnego. Rezygnuje z niepotrzebnych zakupów i wybiera dobra, które nie szkodzą środowisku oraz nie ograniczają możliwości zaspokojenia potrzeb innych konsumentów. Ma coraz większą świadomość swojego otoczenia, zarówno społecznego, jak i naturalnego, wynikającą $z$ adaptacji zasad zrównoważonego rozwoju. Jest otwarty na nowe wzory i style konsumpcji, poprzez które wyraża siebie i swój stosunek do otaczającej go rzeczywistości.

Celem artykułu jest przedstawienie wpływu nowoczesnych technologii na wybrane aspekty zachowań współczesnych konsumentów oraz określenie przesłanek decydujących o zmianie tradycyjnego modelu konsumpcji. Przedmiotem badań są postawy i zachowania konsumenckie pokolenia $\mathrm{Z}$ oraz preferowane alternatywne modele konsumpcji. Badaniem objęto najmłodsze pokolenie konsumentów, którego charakterystyka została dokonana w pierwszej części artykułu wraz z określeniem uwarunkowań jego rozwoju. Sformułowano hipotezę o kształtowaniu się nowego oblicza procesu podejmowania decyzji zakupowych przez pokolenie $\mathrm{Z}$, mocno związanego z wykorzystaniem urządzeń mobilnych. Potwierdzono ją w dalszej części pracy, wskazując sposób, w jaki nowe technologie wpływają na realizację potrzeb konsumentów oraz kształtują ich postawy i zachowania rynkowe. Podjęto też próbę odpowiedzi na pytanie o przyczyny zmiany mentalności i stylu życia najmłodszej generacji, która wykazuje się racjonalnością w zaspokajaniu potrzeb, odchodzi od nadmiarów i potrafi wspólnie użytkować rzeczy. 


\section{Teoretyczny aspekt badań}

Współczesne pokolenie nastolatków jest otwarte na nowe technologie i doskonale odnajduje się w przestrzeni wirtualnej, którą traktuje jako dogodne miejsce do wyszukiwania informacji, wyrażania swoich poglądów czy kontaktowania się z firmami. Młodzi konsumenci korzystający z mobilnych urządzeń podczas podejmowania decyzji zakupowych sięgają do opinii i komentarzy zamieszczonych $\mathrm{w}$ internecie, wymieniają się spostrzeżeniami i doświadczeniami oraz porównują ceny i cechy towarów. Zważywszy na dynamicznie rozwijający się rynek mobilny, należy stwierdzić, że interaktywny i multimedialny charakter konsumpcji jawi się jako jeden z najistotniejszych kierunków jej rozwoju. Rozpoznanie tego trendu jest wyzwaniem dla przedsiębiorstw, które stoją przed koniecznością reakcji zarówno na zmieniające się mobilne otoczenie technologiczne, jak i na nowe, wyłaniające się pokolenie konsumentów. Współczesne firmy, które kierują do niego swoją ofertę, powinny budować odpowiednie strategie marketingowe i biznesowe, dostosowane do potrzeb najmłodszych uczestników rynku. Dlatego też kwestia zmiany postaw konsumenckich pokolenia $\mathrm{Z}$ nabiera znaczenia nie tylko poznawczego, ale i aplikacyjnego, objawiającego się możliwością podjęcia przez producentów działań zgodnych z oczekiwaniami znaczącej grupy młodych, mobilnych nabywców. Tymczasem problematyka ta jest fragmentarycznie opisana w polskiej literaturze naukowej. Istniejące publikacje mają w większości ogólny charakter i koncentrują się na analizie cech przedstawicieli kolejnych generacji, nieznacznie tylko związanych $\mathrm{z}$ ich zachowaniami konsumenckimi. Pokolenie $\mathrm{Z}$ nie zostało jeszcze szczegółowo przebadane zwłaszcza w kontekście reorientacji postaw nabywczych, co skłoniło autorkę artykułu do szczegółowej analizy tego zagadnienia.

\section{Metodologia badań}

Opracowanie ma charakter teoretycznych rozważań nad tematyką zachowań rynkowych pokolenia $\mathrm{Z}$ i powstało przy wykorzystaniu wtórnych źródeł informacji. Dokonano w nim przeglądu najważniejszych pozycji naukowych poświęconych omawianej tematyce oraz przedstawiono poglądy różnych autorów. W celu realizacji problemu badawczego przeprowadzono studia literaturowe, które wsparto analizą danych empirycznych oraz danych pochodzących z raportów i opracowań różnych instytucji dostępnych $w$ internecie oraz w bazach danych. Na tej podstawie usystematyzowano wiedzę dotyczącą ewolucji postaw konsumenckich pokolenia $\mathrm{Z}$ na skutek rozwoju mobilnych technologii oraz nowych trendów w konsumpcji. 


\section{Charakterystyka pokolenia Z}

Obecne pokolenie nastolatków jest określane w literaturze jako pokolenie $\mathrm{Z}$ i choć nazwa ta nie ma formalnego uzasadnienia, to jest najbardziej rozpowszechniona w opracowaniach naukowych i mediach. W użyciu są także inne określenia wskazujące na bardzo mocne przywiązanie reprezentantów tej generacji do nowych technologii, zwłaszcza do internetu i urządzeń mobilnych, to jest Digital Natives, iGeneration, Screeners czy Selfie Generation (Grabiwoda, 2019, 50). Niektórzy autorzy (Aniszewska, 2015, 6; Hysa, 2016, 389) stosują nazwę „generacja C” (od connected, czyli podłączony do sieci). Natomiast określenie 9/11 Generation, popularne zwłaszcza w Stanach Zjednoczonych, nawiązuje do ataków terrorystycznych z 11 września 2001 roku.

Podobnie jak w przypadku braku spójnego i ugruntowanego nazewnictwa, nie istnieją oficjalnie uznane ramy czasowe dla tej generacji. Ich jednoznaczne określenie jest bardzo trudne, chociażby z uwagi na przenikanie się pokoleń. W opracowaniach naukowych wyodrębnia się pokolenie Y i Z jako dwie generacje młodych osób. B. Mróz (2013, 73), powołując się na ustalenia D. Tapscotta, zalicza do pokolenia Y, nazywanego też ,pokoleniem sieci” (net generation), ,pokoleniem milenijnym” (millenials) czy „następną generacją” (next generation), osoby urodzone w latach 1977-1997. Z kolei J. van den Bergh i M. Behrer (2012, 21) uważają, że pokolenie sieci przyszło na świat w latach 1980-1996. Jeszcze innego zdania jest G. Aniszewska $(2015,3)$, według której przedział czasowy dla tej generacji obejmuje lata 1980-1994. Ze względu na wielość stanowisk dotyczących okresu urodzeń pokolenia $Y$ trudno precyzyjnie ustalić jego początek dla najmłodszej generacji. Zważywszy jednak na największą powtarzalność dat w analizowanych opracowaniach (Grabiwoda, 2019, 16; Aniszewska, 2015, 3; Hysa, 2016, 387), można przyjąć, że jest to rok 1995.

Wśród powodów wyodrębnienia pokolenia $\mathrm{Z}$ jako niezależnej grupy społecznej wymienia się skok technologiczny w latach 1990-2000, obejmujący szybkie rozprzestrzenianie się internetu i rozwój telefonii komórkowej. O ile poprzednia generacja stopniowo wkraczała w cyfrową rzeczywistość, przenosząc do niej kolejne elementy swojego życia, o tyle pokolenie $\mathrm{Z}$ nie zna świata bez internetu. Od najmłodszych lat funkcjonuje w wirtualnym wymiarze, który traktuje jako dogodną płaszczyznę do nauki, zabawy, zdobywania informacji, komunikowania się czy zawierania znajomości, bez konieczności podejmowania tych aktywności w świecie rzeczywistym. Jego reprezentanci są nieustannie podłączeni do sieci, publikując treści i zamieszczając informacje, których celem jest kreowanie własnego wizerunku oraz wzbudzenie pozytywnej reakcji obserwatorów. Przejawiają dużą intensywność wirtualnych kontaktów, które często są nadrzędne wobec tych utrzymywanych poza siecią. Urządzenia mobilne i media społecznościowe stanowią istotny element nowego stylu życia tej generacji, wpływający na sposób spędzania czasu, model utrzymywania relacji czy proces podejmowani decyzji zakupowych. 
Zakres wykorzystania nowoczesnych technologii nie jest jedynym kryterium wyróżniającym pokolenie Z, którego rozwój przypadł na okres dynamicznych przemian ekonomicznych oraz kształtowania się globalnej gospodarki. Epoka koncentracji i standaryzacji produkcji oraz dyfuzji jednolitych wzorów konsumpcji sprawiła, że przedstawiciele najmłodszej generacji akceptują efekty tych procesów bardziej niż ich poprzednicy i w większym stopniu z nich korzystają. Są entuzjastycznie nastawieni wobec możliwości, jakie dają nowoczesne technologie i przejawiają określone sposoby zachowań, które wynikają z nabywania produktów i marek globalnych. Jednocześnie są świadomi zagrożeń, jakie niesie za sobą intensywny rozwój gospodarczy w postaci wzrostu zużycia zasobów, zanieczyszczenia środowiska i marnotrawstwa. Ta niespójność w zachowaniach pokolenia $Z$ jest odzwierciedleniem zjawiska nazwanego przez B. Mroza $(2013,27)$ selektywną adaptacją, które oznacza częściowe przystosowanie i częściowe odrzucenie. Podobne stanowisko prezentuje B. Grabiwoda (2019, 63), która twierdzi, że współcześni młodzi konsumenci przejawiają niezwykłą łatwość korzystania z pozytywnych aspektów globalizacji przy jednoczesnej mocno zarysowującej się świadomości jej negatywnych implikacji. Dostrzegają destrukcyjny wpływ masowej produkcji i konsumpcji na środowisko oraz skutki nieuczciwych praktyk wielkich korporacji, w efekcie czego dokonują bardziej świadomych i etycznie odpowiedzialnych wyborów konsumenckich (Grabiwoda, 2019, 117).

Rozbieżność preferencji generacji $Z$ przejawia się $w$ dwu sprzecznych tendencjach: naśladownictwa i indywidualizacji (Grabiwoda, 2019, 64). Z jednej strony reprezentujące ją osoby tworzą najbardziej homogeniczną grupę, która z łatwością ulega zunifikowanym trendom kreowanym przez media oraz modzie na jednorodne produkty i marki proponowane przez globalne firmy. $\mathrm{Z}$ drugiej strony oczekują oni spersonalizowanych produktów i usług, dostosowanych do indywidualnych potrzeb, które podkreślą ich wyjątkowość i oryginalność. Pragną wyróżnić się poprzez konsumpcję i wykreować własny niepowtarzalny wizerunek. Niespójność w zachowaniach młodych nabywców przejawia się zatem w stopniowym ujednoliceniu i standaryzacji postaw przy mocno zarysowującej się potrzebie indywidualizacji i podkreślenia własnej odrębności.

Istotnym czynnikiem, który wyróżnia pokolenie Z spośród innych, jest świadomość globalnych problemów politycznych i gospodarczych. Ataki terrorystyczne w USA z 11 września 2001 roku i następujące po nich wydarzenia, w których cieniu reprezentanci tego pokolenia się wychowywali, wpłynęły na narastające wśród nich poczucie zagrożenia i strachu. Podobnie podziałał kryzys gospodarczy z 2008 roku, który spowodował problemy na rynku pracy, spadek płac, wzrost niepewności zatrudnienia i bezrobocia oraz nasilił trudności ze spłatą zobowiązań finansowych. Można zatem powiedzieć, że występujące w tym samym okresie światowe kryzysy — terrorystyczny i ekonomiczny — ukształtowały pokolenie Z, które cechuje realizm. W przeciwieństwie do optymistycznych, odważnych i pewnych siebie millenialsów, wychowanych na przełomie lat osiemdziesiątych 
i dziewięćdziesiątych XX wieku, a więc w okresie pokoju i gospodarczej stabilizacji oraz pozytywnych nastrojów społecznych, generacja $\mathrm{Z}$ ma pesymistyczny stosunek do rzeczywistości. Jej przedstawiciele wskazują na niestabilność i niepewność co do swojej przyszłości. Obawiają się o dostępność miejsc pracy, wyrażają niepokój związany ze wzrostem cen i deklarują potrzebę oszczędzania (Grabiwoda, 2019, 62).

Potencjał generacji $\mathrm{Z}$ wynika $\mathrm{z}$ tego, że jest to obecnie najszybciej rosnącą grupa konsumentów na świecie, która stanowi $25,9 \%$ globalnej populacji, czyli około 1,9 mld osób (o 1,5\% więcej niż pokolenie Y), a z szacunków wynika, że do 2020 roku będzie ona stanowić nawet $40 \%$ populacji na największych rynkach, między innymi w USA, Europie czy Chinach (Grabiwoda, 2019, 51).

\section{Wpływ technologii mobilnych na zachowania konsumentów $\mathrm{z}$ pokolenia $\mathrm{Z}$}

Młodzi konsumenci urodzeni w cyfrowym otoczeniu bez trudu przyswajają nowe rozwiązania technologiczne, a nawet inicjują ich rozwój poprzez coraz większą asymilację w codziennym życiu. Dostęp do sieci i zakres jej wykorzystania jest czynnikiem najbardziej determinującym zachowania konsumenckie pokolenia $\mathrm{Z}$ i to w zakresie niespotykanym wcześniej u innych generacji. Rosnąca popularność urządzeń mobilnych zwiększa aktywność jego reprezentantów w wirtualnym środowisku oraz kształtuje ich postawy rynkowe.

Pokolenie Z tworzy transkontynentalną społeczność, której cechy nie są ograniczone terytorialnie. Członkowie tej społeczności są homogeniczną grupą połączoną procesem wirtualizacji, który dotyczy także konsumpcji. Wpływ na natężenie tego procesu ma adaptacja ICT, i to nie tylko przez jedno pokolenie, ale całe społeczeństwo, choć nie ulega wątpliwości, że najmłodsza generacja najszybciej i najchętniej przyswaja nowe rozwiązania. Zakres ich zastosowania różni się w zależności od kraju, co rzutuje także na to, w jaki sposób są one wykorzystywane w procesie konsumpcji. The Global Competitiveness Report opublikowany przez World Economic Forum w 2019 roku wskazuje, że w Polsce proces adaptacji ICT ciągle postępuje, a na 141 krajów Polska zajęła pod tym względem 51. miejsce (World Economic Forum, 2019, 468). Optymistyczne są także notowania dotyczące użytkowników internetu, których liczba ciągle rośnie i obecnie jest szacowana na poziomie 77,5\% dorosłej populacji (World Economic Forum, 2019, 468). O zwiększającej się skali wykorzystania nowych technologii świadczą także liczne badania krajowe, jak chociażby raport Polacy na zakupach opracowany przez PwC (Pricewater house Coopers) na podstawie metody ankietowej, z którego wynika, że polscy konsumenci coraz chętniej kupują mobilnie. Szczególnie dynamicznie rośnie grupa użytkowników smartfonów - zakupów za ich pośrednictwem dokonuje przynajmniej raz w tygodniu $17 \%$ badanych, w tym 7\% codziennie (PwC, 2018, 5). Wzrasta liczba 
osób korzystających z różnego rodzaju aplikacji zarówno do nabywania towarów, jak i do realizacji kuponów i kodów rabatowych — w 2017 roku użytkowało je około 41\% badanych (PwC, 2018, 7). Popularne stają się też płatności mobilne - 39\% respondentów chętnie opłaca $w$ ten sposób codzienne zakupy, podczas gdy $31 \%$ nie stosuje tej formy płatności (PwC, 2018, 12).

Współcześni nabywcy ufają recenzjom i rekomendacjom prezentowanym w sieci, które mają często większy wpływ na ich wybory zakupowe niż przekazy marketingowe sprzedawców, takie jak reklamy czy promocje. Aż 58\% ankietowanych przez $\mathrm{PwC}$ szuka inspiracji zakupowych w mediach społecznościowych, a 42\% korzysta z porównywarek cen (PwC, 2018, 18).

W Polsce wyraźnie nasila się zjawisko multiscreeningu, polegające na używaniu kilku urządzeń elektronicznych jednocześnie (na przykład TV i telefonu). $\mathrm{Z}$ badań przeprowadzonych przez Ipsos na zlecenie Google w Polsce, Czechach, Grecji i na Ukrainie (Protasiuk, 2018) wynika, że Polacy są „dwuekranowcami”, co oznacza, że częściej niż konsumenci z pozostałych trzech krajów podczas oglądania telewizji korzystają ze smartfonów do przeglądania ofert, poszukiwania informacji i podejmowania decyzji zakupowych. Jak podkreśla B. Mróz $(2013,79)$, tendencja ta jest zauważalna zwłaszcza wśród najmłodszego pokolenia, które potrafi korzystać równocześnie z kilku urządzeń do symultanicznego wykonywania wielu czynności (multitasking).

Ciekawych informacji na temat przemian w zachowaniach konsumentów będących wynikiem poszerzającego się spektrum możliwości oferowanych przez technologie mobilne dostarcza najnowszy raport Publicis Groupe zatytułowany (Kręte) ścieżki konsumenta w e-commerce. Pokazuje on, że korzystanie z możliwości technologicznych wpływa na kształtowanie się nowego oblicza procesu zaspokajania potrzeb, mocno związanego z rozwojem rynku e-commerce (handel elektroniczny) i m-commerce (handel mobilny). W Polsce już 19,5 mln konsumentów regularnie kupuje $\mathrm{w}$ sieci, coraz więcej za pomocą aplikacji, a najpopularniejsze z nich, jak Rossmann, Lidl, Biedronka czy Żabka, mają już kilkumilionową liczbę użytkowników (Publicis Groupe, 2019, 4-5). Z kolei Allegro — największa platforma e-commerce - deklaruje, że co trzeci jej klient realizuje transakcje właśnie mobilnie (Publicis Groupe, 2019, 5).

W 2018 roku udział branż e-commerce i m-commerce w sprzedaży detalicznej w Polsce ogółem wyniósł 7\%, a prognozy rynkowe są mobilizujące i zakładają dalszy wzrost do 10\% w perspektywie najbliższych trzech lat (Publicis Groupe, 2019, 5). W krajach Europy Zachodniej ten udział jest zdecydowanie większy. W Wielkiej Brytanii, najbardziej rozwiniętym europejskim rynku e-commerce, prawie jedna piąta zakupów jest realizowana w cyfrowych kanałach. W USA udział sprzedaży e- i m-commerce w całości handlu kształtuje się na poziomie 13\%, a najwyższy na świecie jest w Chinach i wynosi aż 30\% (Publicis Groupe, 2019, 2).

Konsumenci coraz chętniej włączają urządzenia mobilne do swojego procesu zakupowego na różnych jego etapach. Według raportu Izby Gospodarki Elektro- 
nicznej, sporządzonego na podstawie badania ponad 2 tys. Polaków pt. $M$-commerce. Kupuję mobilnie 2016, aż 45\% internautów posiadających więcej niż jedno urządzenie z dostępem do sieci (na przykład PC, laptop, tablet itp.) zadeklarowało użycie smartfona w kontekście zakupowym na przykład do poszukiwania inspiracji, ofert i dokonywania transakcji (Izba Gospodarki Elektronicznej, 2016, 15). Popularność smartfona ciągle wzrasta, głównie wśród kobiet oraz mieszkańców mniejszych miast i wsi, a także wśród najmłodszych konsumentów w wieku 1518 lat (Izba Gospodarki Elektronicznej, 2016, 16-18). Spośród m-konsumentów $39 \%$ deklaruje regularne zakupy z wykorzystaniem urządzeń mobilnych (Izba Gospodarki Elektronicznej, 2016, 20). Osoby, które podejmują decyzję zakupową na smartfonie lub tablecie, znacznie częściej kończą zakup w ten sam sposób. Wśród osób deklarujących podejmowanie decyzji zakupowych na smartfonie aż trzy czwarte kupuje produkt z wykorzystaniem smartfona (Izba Gospodarki Elektronicznej, 2016, 20). Konsumenci kupujący i płacący mobilnie preferują szybkie przelewy typu PayU czy Dotpay (66\%), płatność kartą płatniczą (50\%), co trzeci płaci dedykowaną aplikacją, a co dziesiąty korzysta z płatności odroczonych i kodów jednorazowych (Izba Gospodarki Elektronicznej, 2016, 64).

Osoby, które deklarują zakupy mobilne, są też znacznie bardziej aktywne jeśli chodzi o wykorzystanie swoich urządzeń w całym procesie około zakupowym niż osoby, które nie kupują mobilnie. Znacznie częściej porównują w ten sposób ceny i oferty, poszukują informacji i opinii, zamieszczają recenzje, ale także, co ciekawe, sprawdzają lokalizację sklepów stacjonarnych i dostępność towarów w sklepach. Najwyraźniej zakupy mobilne nie zniechęcają większości konsumentów do zakupów offline, a urządzenia mobilne takie zakupy dodatkowo wspierają. Konsumenci mobilni wykorzystują smartfony i tablety podczas swoich wizyt w sklepach stacjonarnych, chociażby po to, aby zrealizować kupony i zniżki, które otrzymali mailowo, oraz aby wykonać wiele innych czynności zakupowych, między innymi sprawdzić cenę i opinię o produkcie, który zamierzają kupić, zrobić zdjęcie, które pomoże im podjąc decyzję w domu lub skonsultować ją z rodziną czy znajomymi. Zjawisko polegające na odwiedzaniu sklepów stacjonarnych w celu zapoznania się z produktem, którego zakup odbywa się następnie online, nosi nazwę showroomingu (Izba Gospodarki Elektronicznej, 2016, 37). Jak wskazuje B. Grabiwoda (2019, 118), jest popularne zwłaszcza wśród pokolenia $Z$, jednak jako że coraz więcej nastolatków bierze aktywny udział w podejmowaniu wspólnych rodzinnych decyzji zakupowych, znajduje naśladowców także wśród starszych pokoleń.

Badania z 2016 roku, podjęte przez B. Grabiwodę, nad procesem podejmowania decyzji zakupowych przez pokolenie $Z$ objęły 523 respondentów (259 kobiet i 264 mężczyzn) w wieku 15-21 lat, urodzonych w latach 1995-2001, którzy zadeklarowali posiadanie przynajmniej jednego urządzenia mobilnego $(2019,171)$. Pokazały one rosnący wpływ rozwiązań mobilnych na zachowania konsumenckie polskiej młodzieży, w tym zwłaszcza na sposób podejmowania decyzji zakupowych, a także na kształtowanie się jej potrzeb. Okazało się, że niebagatelną rolę w tym względzie 
odgrywają przekazy od firm w postaci zdjęć, reklam czy informacji o ofercie lub promocjach, umieszczane na urządzeniach mobilnych. Większość badanych (53\%) potwierdziła, że zwraca uwagę na komunikaty od firm wyświetlane na smartfonach i tabletach, a także przyznała, że są one dla nich przydatne (46\%) (Grabiwoda, 2019, 201). Ponad połowa (55\%) oceniła je jako zachęcające do rozważenia lub zaplanowania zakupu produktu czy usługi (Grabiwoda, 2019, 205). To właśnie ten sposób reklamy badani uznali za jeden z najbardziej skutecznych (46\%) zaraz obok reklamy telewizyjnej (47\%) (Grabiwoda, 2019, 199).

Korzystanie ze smartfonów i tabletów podczas szukania informacji o produktach lub firmach zadeklarowało aż 89\% respondentów (Grabiwoda, 2019, 184). Najczęściej wybieranymi przez nich sposobami pozyskiwania informacji były wyszukiwarki, komunikatory internetowe, treści wideo, blogi i fora tematyczne. Nieco mniej, bo $71 \%$ ankietowanych przyznało, że wykorzystuje smartfony lub tablety do oceny i porównywania produktów (Grabiwoda, 2019, 188). Ponad połowa respondentów (55\%) wskazała, że dokonuje zakupów za pośrednictwem urządzeń mobilnych, przy czym 57\% korzysta w ten sposób z usług bankowych, $30 \%$ rezerwuje bilety, a $12 \%$ dokonuje innych transakcji, na przykład zamawia taksówki czy umawia się na wizyty lekarskie (Grabiwoda, 2019, 191).

Badanie ujawniło, że młode pokolenie chętnie korzysta z urządzeń mobilnych także w procesach pozakupowych $-89 \%$ badanych potwierdziło, że ocenia za ich pomocą dobra lub usługi głównie poprzez wypełnienie ankiety czy przyznanie punktów, $70 \%$ kontaktuje się z firmą, pisząc komentarz, dodając post na profilu lub stronie internetowej producenta, a ponad połowa respondentów za pomocą urządzeń mobilnych informuje znajomych o produkcie bądź publikuje treści (tekst, zdjęcie, wideo) na swoim profilu społecznościowym (Grabiwoda, 2019, 193).

$\mathrm{Na}$ podstawie przeanalizowanych wyników badań można stwierdzić, że zachowania konsumentów $\mathrm{z}$ pokolenia $\mathrm{Z}$ są zdeterminowane przez nowe technologie. Zakres ich wykorzystania kształtuje na nowo proces zaspokajania potrzeb i zmienia sposób podejmowania decyzji zakupowych. Rosnące zaangażowanie konsumentów w mobilną rzeczywistość przekłada się na coraz większą popularność mediów społecznościowych (Facebook, Instagram, Snapchat), które usprawniają sposób, w jaki konsumenci komunikują się z sobą i z firmami, dzielą się informacjami oraz podejmują decyzje o nabyciu towarów.

\section{Nowy model konsumpcji generacji Z}

Model konsumpcji pokolenia $\mathrm{Z}$ jest mocno osadzony w rzeczywistości wirtualnej i opiera się na technologiach mobilnych. Młodzi konsumenci poruszają się swobodnie w sieci i traktują internet jako najwygodniejszą i najtańszą formę zakupów, których dokonują przy użyciu smartfonów i tabletów. Wykorzystują je na znacznie szerszą skalę niż starsze pokolenia, od których odróżniają się też nastawieniem do proce- 
su konsumpcji. Charakteryzuje ich rosnący dystans wobec tradycyjnych wzorów spożycia opartych na zwiększaniu stanu posiadania. W. Kozłowski i A. Rutkowska $(2016,243)$ wprost wskazują na „zmianę paradygmatu funkcjonowania konsumenta na rynku", który neguje bezmyślną konsumpcję i odchodzi od wyrażania swojej osobowości poprzez niepohamowane dążenie do gromadzenia dóbr. Przekształca się w świadomego i odpowiedzialnego nabywcę, którego cechuje troska o środowisko naturalne oraz spadek zaufania do etycznej strony praktyk biznesowych firm.

Wyrazem reorientacji postaw nabywców z pokolenia $\mathrm{Z}$ i ich rosnącego sceptycyzmu wobec dalszego wzrostu konsumpcji jest wybór alternatywnych form zaspokajania potrzeb. Jednym z nich jest konsumpcja kolaboratywna (collaborative consumption), zwana inaczej współpracującą (wspólną) lub ekonomią dzieloną (sharing economy) (Zalega, 2016, 215-216), która opiera się na dostępie do dóbr, realizowanym bez konieczności posiadania i przenoszenia praw własności. Polega na pożyczaniu, wynajmowaniu, umowach barterowych czy też wymianie, a do obszarów, w których jest najbardziej rozwinięta, należą: transport, turystyka, zamieszkanie, finanse, jedzenie, ubrania, czas wolny.

Konsumpcja kolaboratywna w znacznie mniejszym stopniu dotyczy akumulacji dóbr, a w większym poprawy efektywności ich wykorzystania. Polega na oddolnych inicjatywach indywidualnych osób, które udostępniają innym swoje zasoby poprzez platformy internetowe i aplikacje, za opłatą, na zasadzie współdzielenia kosztów lub bezpłatnie. Opiera się na relacjach P2P, czyli „każdy z każdym", a więc na dzieleniu i wymienianiu się zasobami bez zaangażowania instytucji pośredniczących (sklepów, banków, agencji). Uczestnikami konsumpcji kolaboratywnej są głównie ludzie młodzi, aktywni w mediach społecznościowych, otwarci na nowe doświadczenia, ale równocześnie mający ograniczone możliwości finansowe i szukający tańszych rozwiązań. Dzięki bezpośrednim kontaktom nawiązywanym w sieci uzyskują dostęp do dóbr i usług, na przykład hotelarskich czy taksówkowych, na które dotychczas nie było ich stać. Traktują więc to rozwiązanie jako o wiele korzystniejsze cenowo niż zakup dóbr na własność i chętnie z niego korzystają. W ten sposób realizują swoje potrzeby i aspiracje bez żadnych ograniczeń ilościowych, jednak w bardziej racjonalny i odpowiedzialny sposób. Mogą doświadczać tego, co oferują różnorodne produkty, przy jednoczesnym pozbyciu się obowiązków i odpowiedzialności wynikającej z własności (na przykład nie jest konieczne ponoszenie kosztów utrzymania, ubezpieczenia czy serwisowania). Zyskują też sposobność zaakcentowania własnej indywidualności między innymi poprzez korzystanie z niestandardowych dóbr i usług, których nie są w stanie zapewnić tradycyjne firmy oferujące masową produkcję.

Wzrost zainteresowania koncepcją współdzielenia należy tłumaczyć zmianami preferencji i oczekiwań młodych konsumentów, którzy poszukują tanich, wygodnych i efektywnych rozwiązań, a równocześnie pozostających w zgodzie z troską o środowisko. Zdaniem A. Matel $(2016,60)$ charakterystyczna dla kon- 
sumpcji wspólnej możliwość korzystania z dóbr bez konieczności ich posiadania jest przejawem coraz większej świadomości ekologicznej konsumentów. Młodzi nabywcy, odpowiedzialni za stan środowiska naturalnego, z dystansem podchodzą do bezmyślnego gromadzenia dóbr, które skutkuje marnotrawstwem, wyczerpywaniem się zasobów oraz zwiększaniem ilości odpadów i zanieczyszczeń. I. Escher i J. Petrykowska $(2015,129)$ wskazują na zmianę mentalności i stylu życia obecnej generacji, która nie tylko deklaruje chęć zrównoważenia poziomu konsumpcji, ale też przejawia zachowania określane mianem proekologicznych. Młode pokolenie dzięki edukacji ekologicznej nabyło niezbędną wiedzę i wykształciło nawyki sprzyjające poszanowaniu środowiska przyrodniczego oraz stało się bardziej otwarte na adaptację alternatywnych form konsumpcji.

Ważnym czynnikiem rozpowszechnienia wśród pokolenia $\mathrm{Z}$ rozwiązań z zakresu konsumpcji wspólnej jest aspekt finansowy. Jego reprezentanci są w dużej mierze zależni od swoich rodziców i świadomi ich sytuacji materialnej, dlatego poszukują bardziej efektywnych kosztowo rozwiązań niż posiadanie. Chętnie decydują się na współkonsumpcję, która z jednej strony pozwala im zaoszczędzić środki, a z drugiej — zyskać na wymianie czy wypożyczaniu za opłatą. Jej skala ciągle się zwiększa, do czego przyczynił się kryzys gospodarczy z 2008 roku, który, jak podkreśla A. Koźlak (2017, 179-180), skłonił wielu nabywców do większego pragmatyzmu i racjonalizacji wydatków. Wymusił pewne zmiany adaptacyjne w postaci rezygnacji z własności na rzecz tańszej i dogodniejszej formy zaspokojenia potrzeb, czyli uzyskania dostępu do dóbr i ich funkcjonalności. Jednocześnie pobudził kreatywność ludzi poszukujących możliwości poprawy swojej sytuacji finansowej i zarobienia pieniędzy. Sprawił, że na znaczeniu zyskał rozwijający się na podstawie wspólnej konsumpcji trend prosumpcji, który — jak podaje E. Szul (2013, 347-348) - polega na wzajemnym przenikaniu się konsumpcji i produkcji aż do zatarcia granic między nimi, w wyniku czego konsumenci stają się jednocześnie przedsiębiorcami, producentami, dostawcami, gdyż w takiej roli sytuuje ich posiadanie określonych zasobów. Jako prosumenci, a więc konsumenci i producenci w jednym, wykorzystują platformy internetowe do udostępnienia innym swoich niezagospodarowanych aktywów (materialnych i niematerialnych), dzięki czemu zwiększają ich wydajność. Niewykorzystane zasoby oddane $\mathrm{w}$ czasowe użytkowanie innym osobom mogą przysporzyć ich właścicielowi dodatkowego dochodu bądź poszerzyć grono jednostek partycypujących w kosztach utrzymania. Idea prosumpcji opiera się zatem na koncepcji konsumpcji innowacyjnej, która nie umniejsza finansów konsumenta, ale przynosi mu dodatkowe korzyści dzięki jego kreatywności. M. Mitręga i O. Witczak $(2012,440)$ traktują prosumpcję jako przejaw konsumenckiej przedsiębiorczości. Rozważają nawet tezę, że prosumpcja jest synonimem przedsiębiorczości w odniesieniu do zachowań konsumenta na rynku.

Prosumenci wywodzą się głównie z internetowo-cyfrowego pokolenia, które odchodzi od jednowymiarowego uczestnictwa w konsumpcji na rzecz wzmoc- 
nienia postaw przedsiębiorczych przez oferowanie posiadanych przez siebie zasobów innym osobom zainteresowanym ich użytkowaniem. Jego przedstawiciele przejawiają umiejętność współdzielenia się własnością i samoograniczenia prawa do wyłącznego użytkowania rzeczy. Bez trudu integrują działania konsumenckie i producenckie, w czym upatrują szans na zwiększenie swoich dochodów i siły nabywczej, a także na rozszerzenie aktywności ekonomicznej. Podejmowane przez nich działania prosumenckie prowadzą do rozwoju alternatywnych form zatrudnienia (tak zwane samozatrudnienie) i elastycznych modeli pracy (wykonywanej okresowo i w niepełnym wymiarze czasu w porównaniu do pracy na etacie), które mają wpisane w swoją konstrukcję elementy autonomii działania, szerokiego wyboru i elastyczności. Są to cechy ważne dla pokolenia Z, spójne z potrzebą swobody i wolności wyboru. Prosumpcja odpowiada oczekiwaniom jego reprezentantów, którzy na pierwszym miejscu stawiają kreatywność, samodzielność i niezależność oraz oczekują interesujących wyzwań zawodowych. Potwierdza to badanie ankietowe przeprowadzone wśród 1327 internautów na potrzeby raportu Pracownik przyszłości (2019, 16-19) z którego wynika, że kreatywność w wykonywaniu zadań jest ważna dla co czwartego respondenta z pokolenia Z (26\%), podczas, gdy dla millenialsów liczy się zwłaszcza rozwój posiadanych umiejętności i kwalifikacji (14\%). Natomiast na zarobki wskazał zaledwie co piąty przedstawiciel generacji Z (19\%) i prawie co trzeci badany w wieku 23-34 lata (24\%).

Raport ujawnił też, że praca na etat w pełnym wymiarze godzin przestała być jedyną preferowaną formą zatrudnienia, o czym świadczy niewielka liczba pozytywnych wskazań - tylko 26\% ogółu ankietowanych i 18\% respondentów z pokolenia Z. Wzrosło natomiast znaczenie bardziej elastycznych form pracy, takich jak telepraca wykonywana zdalnie za pośrednictwem internetu czy telefonu, na którą wskazało analogicznie 21\% i 11\% badanych, ale także tych dających większą niezależność i możliwość podejmowania decyzji, takich jak freelancing (odpowiednio 17\% i 9\%) oraz prowadzenie własnej działalności (19\% i 28\%). Na pracę etatową w niepełnym wymiarze godzin wskazało $17 \%$ ogółu respondentów i 33\% przedstawicieli pokolenia Z. Wyraźne odejście od tradycyjnego sposobu rozumienia pracy jest cechą odróżniającą najmłodszych pracowników od millenialsów, którzy doskonale odnajdują się w pełnoetatowej pracy w korporacjach. Reprezentanci pokolenia $\mathrm{Z}$ pragną podążać własną drogą, a sukces zawodowy wiążą z prowadzeniem własnego biznesu będącego często odzwierciedleniem ich zainteresowań czy pasji (Grabiwoda, 2019, 54).

\section{Wnioski}

Konsumpcja XXI wieku jest naznaczona zmianami technologicznymi, które kształtują jej oblicze. Najszybciej adaptuje się do nich pokolenie Z, które preferuje nowy styl życia i konsumpcji skoncentrowany wokół internetu i rozwiązań 
mobilnych. Wysoka częstotliwość użycia smartfonów i tabletów przez jego reprezentantów zmienia sposób zaspokajania potrzeb oraz wpływa na kształtowanie się nowych form procesów zakupowych. Zwiększająca się skala aktywności pokolenia $\mathrm{Z}$ w środowisku internetowym jest wyzwaniem dla firm, które poszukują skutecznych sposobów komunikacji marketingowej w coraz większym stopniu obejmujących media mobilne. Dopasowują też swoje strategie do oczekiwań najmłodszej generacji, dla której konsumpcja jest nie tylko prostym aktem zaspokojenia potrzeb, ale przede wszystkim okazją do zademonstrowania określonego systemu wartości, wyrażenia swoich poglądów, postaw i zaakcentowania niezależności. Znajduje to odzwierciedlenie w zmianie zachowań konsumenckich tego pokolenia, którego przedstawiciele coraz częściej rezygnują z własności i wybierają alternatywne sposoby zaspokajania potrzeb, oparte na wymianie, pożyczaniu i udostępnianiu innym własnych zasobów za pomocą platform i aplikacji. Pragną w ten sposób zamanifestować swój negatywny stosunek do konsumpcyjnego stylu życia, który niesie z sobą określone konsekwencje środowiskowe i społeczne. Wybierają użytkowanie dóbr zamiast posiadania, dzięki czemu mogą nie tylko konsumować taniej, ale też zyskać na udostępnianiu swoich zasobów innym osobom zainteresowanym ich użytkowaniem. W ten sposób kreują nowy typ konsumpcji, który tworzy dodatkowe możliwości zarobkowania i wspiera rozwój prosumpcji.

\section{Bibliografia}

Aniszewska, G. (2015). Zmiany pokoleniowe a decyzje i wybory konsumenckie. Marketing i Rynek, $1,2-7$.

Bergh, J. van den, Behrer, M. (2012). Jak kreować marki, które pokocha pokolenie Y? Warszawa: Samo Sedno.

Escher, I., Petrykowska, J. (2015). Proekologiczne zachowania młodych polskich konsumentów. Handel Wewnętrzny, 2 (355), 128-141.

Grabiwoda, B. (2019). E-konsumenci jutra. Pokolenie Z i technologie mobilne. Łódź: Wydawnictwo Nieoczywiste.

Hysa, B. (2016). Zarządzanie różnorodnością pokoleniową. Zeszyty Naukowe Politechniki Śląskiej. Seria: Organizacja i Zarządzanie, 97, 385-398.

Infuture hatalska foresight institute. (2019). Pracownik przyszłości. Data dostępu: 10.12.2019, https:// images.samsung.com/is/content/samsung/p5/pl/pracownik/pracownik_przyszlosci_2019infuturesamsung.pdf?_ga=2.148243253.360412905.1574439829-1813242068.1573040464.

Izba Gospodarki Elektronicznej. (2016). M-commerce. Kupuję mobilnie 2016. Data dostępu: 10.04.2020, http://ecommercepolska.pl/files/7514/8000/0754/M-commerce_Kupuje_mobilnie_2.0_listopad_2016_2.pdf.

Kozłowski, W., Rutkowska, A. (2016). Konsumpcjonizm a marketing społecznie zaangażowany. W Ejdys, J. (red.), Społeczna odpowiedzialność i zrównoważony rozwój w naukach o zarzadzaniu: aspekty teoretyczne i aplikacyjne (235-251). Toruń: Dom Organizatora, Towarzystwo Naukowe Organizacji i Kierownictwa.

Koźlak, A. (2017). Sharing economy jako nowy trend społeczno-gospodarczy. Prace Naukowe Uniwersytetu Ekonomicznego we Wrocławiu, 489, 171-182.

Ekonomia - Wroclaw Economic Review 26/1, 2020

(C) for this edition by CNS 
Krzepicka, A. (2016). Współczesny konsument — konsument digitalny. Studia Ekonomiczne. Zeszyty Naukowe Uniwersytetu Ekonomicznego w Katowicach, 255, 207-214.

Matel, A. (2016). Przesłanki ekologizacji konsumpcji z perspektywy zachowań konsumenckich. Zarzadzanie. Teoria i Praktyka, 16, 55-61.

Mitręga, M., Witczak, O. (2012). Prosumpcja jako przejaw przedsiębiorczości konsumenckiej. Zeszyty Naukowe Uniwersytetu Szczecińskiego, 724, 431-444.

Mróz, B. (2013). Konsument w globalnej gospodarce. Trzy perspektywy. Warszawa: Oficyna Wydawnicza, Szkoła Główna Handlowa w Warszawie.

Protasiuk, M. (2018). Particularly Polish: The modern path to purchase in Poland. Data dostępu: 10.12.2019, https://www.thinkwithgoogle.com/intl/en-cee/insights-trends/research-data/ particularly-polish-modern-path-purchase-poland/.

Publicis Groupe. (2019). (Kręte) ścieżki konsumenta w e-commerce. Data dostępu: 10.12.2019, http:// raport-ekonsument.pl/Krete $\% 20$ sciezki\%20konsumenta $\% 20 \mathrm{w} \% 20$ ecommerce Raport $\% 20$ 2019.pdf.

PwC. (2018). Polacy na zakupach - 5 filarów nowoczesnego handlu. Data dostępu: 10.12.2019, https://www.pwc.pl/pl/pdf/polacy-na-zakupach-raport-pwc-2018.pdf.

Szul, E. (2013). Prosumpcja jako aktywność współczesnych konsumentów - uwarunkowania i przejawy. Nierówności Spoteczne a Wzrost Gospodarczy, 31, 347-358.

World Economic Forum. (2019). The Global Competitiveness Report. Data dostępu: 10.04.2020, http://www3.weforum.org/docs/WEF_TheGlobalCompetitivenessReport2019.pdf.

Włodarczyk-Śpiewak, K. (2011). Nowoczesne technologie — wyzwanie dla współczesnych konsumentów. Studies \& Proceedings of Polish Association for Knowledge Management, 51, $142-152$

Zalega, T. (2016). Nowe trendy konsumenckie jako przejaw innowacyjnych zachowań współczesnych konsumentów. Nierówności Społeczne a Wzrost Gospodarczy, 46, 202-225.

Ekonomia - Wroclaw Economic Review 26/1, 2020

(C) for this edition by CNS 